\title{
Inbalt des sechsten Bandes (Teil III)
}

Variantenverzeichnis .................. 1

Critische Dichtkunst. Erster Allgemeiner Theil ..... 3

Critische Dichtkunst. Anderer Besonderer Theil .... 79

Nachwort des Herausgebers.................. 169

Quellenverzeichnis ...................... 179

Nacbbemerkung $\ldots \ldots \ldots \ldots \ldots \ldots \ldots \ldots \ldots \ldots$ 